Article

\title{
Profile of Coffee Crops and Management of the Neotropical Coffee Leaf Miner, Leucoptera coffeella
}

\author{
Suzany Aguiar Leite ${ }^{1, *(\mathbb{D})}$, Raul Narciso Carvalho Guedes ${ }^{2}{ }^{\mathbb{D}}$, Mateus Pereira dos Santos ${ }^{1}$, \\ Daniela Ribeiro da Costa ${ }^{1}$, Aldenise Alves Moreira ${ }^{3}$, Sylvana Naomi Matsumoto ${ }^{3}$, \\ Odair Lacerda Lemos ${ }^{4}(1)$ and Maria Aparecida Castellani ${ }^{3}$ \\ 1 Students Graduate Program in Agronomy (Crop Science), State University Southwestern Bahia, \\ Vitória da Conquista 45083-900, Brazil; mateus.santos.0712@gmail.com (M.P.d.S.); \\ danielaribeirodacosta@yahoo.com.br (D.R.d.C.) \\ 2 Departament of Entomology, Federal University of Viçosa, Viçosa 36570-900, Brazil; guedes@ufv.br \\ 3 Departament of Crop Science and Animal Science, Graduate Program in Agronomy (Crop Science), \\ State University Southwestern Bahia, Vitória da Conquista 45083-900, Brazil; \\ aldenise.moreira@gmail.com (A.A.M.); sylvananaomi@yahoo.com.br (S.N.M.); \\ castellani@uesb.edu.br (M.A.C.) \\ 4 Departament of Agricultural and Soil Engineering, Graduate Program in Agronomy (Crop Science), \\ State University Southwestern Bahia, Vitória da Conquista 45083-900, Brazil; olemos@uesb.edu.br \\ * Correspondence: suzanyleite@yahoo.com.br; Tel.: +55-77-3425-9396
}

Received: 10 August 2020; Accepted: 18 September 2020; Published: 28 September 2020

\begin{abstract}
The Neotropical coffee leaf miner is a key coffee pest and in the state of Bahia, one of the major coffee-producing states in the country. The insect finds favorable conditions for its development, causing production losses and intensive use of insecticides. Thus, the objective of the study was to analyze aspects of the profile of coffee crops and the management of the leaf miner, including the use of insecticide for the western and highland regions of Bahia. Data were obtained through questionnaires applied to coffee growers and/or production technicians and included information on the total area, area with coffee, and native vegetation, type of cultivation, cultivars, pest monitoring, methods of control and use, insecticide rotation, and doses used. Descriptive statistical analysis, principal component analysis (PCA), and canonical correlations indicated differences between farm size, and areas with coffee and native vegetation. Chemical pest control prevails as a management strategy in all farms. The results are important for managing the coffee leaf miner while providing an overview and diagnosis of insecticide use in coffee production in the state of Bahia. An increase in the application of systemic insecticides took place in recent years, similarly (same active ingredients) among most coffee growers. This fact increases the risk of selecting populations resistant to insecticides, compromising the management of the leaf miner in the regions.
\end{abstract}

Keywords: chemical subgroup; control methods; integrated pest management; monitoring; survey

\section{Introduction}

Coffee production is an activity of great importance for the Brazilian economy [1], with an estimated production area of 2.1 million hectares. The country is the world's largest producer and exporter with an annual production of 61.7 million $60 \mathrm{~kg}$ sacks of processed coffee, where few states account for more than $90 \%$ of national production [2].

The state of Bahia ranks fourth in Arabica coffee production (Coffea arabica, in the western and highland regions) and conilon coffee production (Coffea canephora, in the coastal region) with production of 76,135 and 40,930 thousand 60-kg sacks, respectively [2]. Coffee production in Bahia stands out on the national scenario due to the quality of coffee produced in the highland region, mainly in 
municipalities located in Diamantina highlands (i.e., Chapada Diamantina), that is responsible for the production of specialty coffees due to the particular climatic conditions [3].

Consumer expansion in new markets has led coffee growers to search for systems for sustainable production. The highland region of Bahia, with municipalities located in the Diamantina highlands, has played an important role in the adoption of measures based on agricultural practices that cause lower environmental impact and greater economic value of the product. Currently, for accessing the European and North American markets, farmers must use methods consistent with the Integrated Pest Management (IPM) philosophy, and not just chemical control methods [4,5].

Modern agriculture considers economic, environmental, ecological, and food security aspects taken into account in management decisions. The adoption of the IPM philosophy in agricultural and forestry crops is consistent with the requirements of the new consumer markets and new vision and trends in agriculture that goes far beyond crop productivity [6,7].

Considering the principles of IPM, the use of control tactics must be based on knowledge about the phytophagous species and its natural enemies, and the pest population growth trends. Decision-making regarding adoption of pest control must use control levels and economic thresholds. If the phytophagous species causing the injury reaches the population level of control, assuming the status of pest, the decision is for intervention aimed at suppressing the population $[8,9]$. If the decision is for chemical control, the choice of the insecticide is of fundamental importance considering not only the effectiveness and price of the product but mainly its selectivity in favor of natural enemies, toxicity, residual power, grace period, persistence, method of application, and formulation [10].

Coffee leaf miner, Leucoptera coffeella (Guérin-Méneville and Perrottet, 1842) (Lepidoptera: Lyonetiidae) is a key crop pest, especially of unshaded coffee, which is prevalent in most Neotropical America and particularly in Brazil. The highest incidences of the coffee leaf miner occur in Central America and mainly in Brazil due to the high infestation rates recorded [11-15]. The damage caused by the insect is a result of injuries caused by its larvae that feed on the palisade parenchyma of coffee leaves, reducing the photosynthetic capacity, which leads to destruction and fall of leaves and, consequently, reducing fruit production [16]. The biological cycle lasts from 28 to 39 days, and four to five generations of the leaf miner may occur per year [17]. In dry periods, the leaf miner incidence in coffee crops increases [18].

In Brazil, the main method used by coffee growers to control the coffee leaf miner is chemical $[19,20]$. Neuroinsecticides are the most widely used, including several organophosphates, carbamates, pyrethroids, and neonicotinoids, some of which are (relatively) persistent in the environment and exhibit low selectivity in favor of natural enemies. The diamide, chlorantraniliprole, is conversely of more recent use against the control of coffee leaf miner and has low impact on non-target insects [21,22].

The management of leaf miner populations is linked to factors such as frequency of insecticide applications and migration of individuals and development of resistant populations, which are of primary importance for the effective control of the species [23]. The neglect of these factors by coffee growers and the frequent use of insecticides in the control of pest species lead to high selection pressure on the pest individuals and the development of resistance to the most frequently used insecticides [24].

The western and highland regions have increased production costs due to the chemical control of the coffee leaf miner. This is the result of the high number of insecticide applications required for the leaf miner control, mainly in the western region, where conditions are more favorable to the pest development [3]. In both of these coffee producing regions of Bahia, insecticide resistance and risk of control failure have already been observed [25]. There are knowledge lacunas related to leaf miner in the main coffee regions of Bahia that can subsidize research and extension actions on IPM in coffee growing. Thus, the objective of the study was to analyze aspects of the profile of coffee crops and the management of leaf miner, including the use of insecticide, for the western and highland regions of Bahia. 


\section{Materials and Methods}

\subsection{Study Sites}

Sampling took place in farms located in the western (Barreiras, Cocos, Luís Eduardo Magalhães, and São Desiderio) and highland regions of Bahia (Barra do Choça, Barra da Estiva, Encruzilhada, Ibicoara, Mucugê, Piatã, and Vitória da Conquista) (Figure 1) between September 2017 and May 2018, totaling 116 farms surveyed (western region (Farms 1 to 21) and highland region (Farms 22 to 116)).

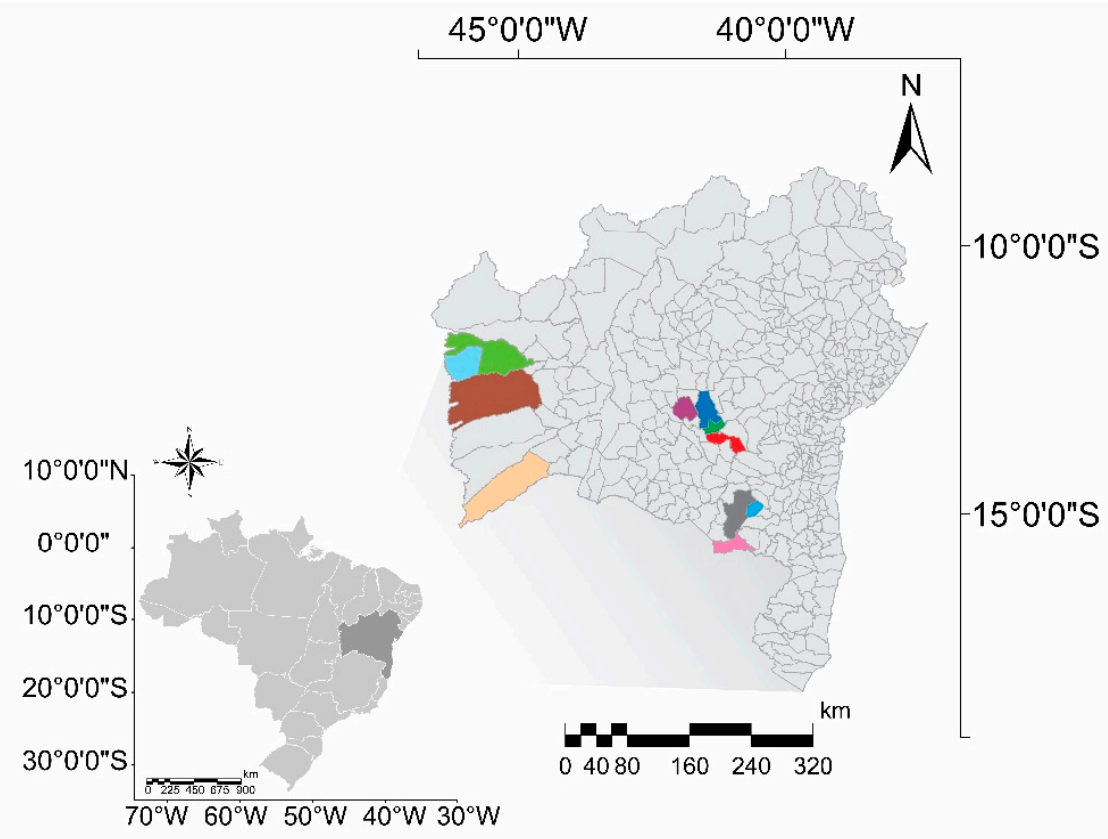

\section{LEGEND}

Counties producing Coffea arabica in the western and south-central highlands

\begin{tabular}{|l|l|l|l|}
\hline BRAZIL & BARRA DO CHOÇA & ENCRUZILHADA & MUCUGÊ \\
\hline BAHIA & BARREIRAS & IBICOARA & PIATÃ \\
\hline BARRA DA ESTIVA & COCOS & LUIS EDUARDO MAGALHÃES & SÃO DESIDÉRIO \\
\hline
\end{tabular}

Figure 1. Municipalities producing Arabica coffee (Coffea arabica), with sampled farms, belonging in the western and south-central highlands regions of the state Bahia.

Information about the profile of coffee crops and management of coffee leaf miner was obtained from coffee growers and/or production technicians. Interviews were carried out in loco, on a voluntary basis, guaranteeing the confidentiality of responses. The questionnaire was designed with structured multiple-choice questions, free and dichotomous responses. Questions involved the following aspects: (1) Farm and cultivation, total area with coffee, area of native vegetation, type of cultivation (irrigated or non-irrigated) and cultivars, (2) history of the area regarding coffee leaf miner monitoring (if so, what level of control is used), types of control adopted, annual frequency of applications, insecticides used, rotation of insecticides, and use of the label rate specified by the manufacturer.

\subsection{Data Analysis}

Data consistency was measured by Cronbach's Alpha coefficient test to verify the reliability and consistency of the group of multiple-choice and dichotomous responses. The intensity of the relations was very high $(\alpha=0.91)$ to moderate $(\alpha=0.65)$.

Questionnaire data were tabulated and analyzed in Microsoft Excel, using the Chi-Square test to determine differences between regions (western and highland) related to the distribution of coffee growers within the characteristics addressed, as well as a multivariate analysis with groupings of 
variables: Total area, area with coffee, area of native vegetation. The adopted technique was the multivariate analysis of PCA (Principal Component Analysis) using the R FactoMinerR package software [26] applying the selected variables to transform data from a wide spectrum to low spectrum space. PCA was calculated using the correlation matrix for each variable to deduce the eigenvector and eigenvalue. The eigenvector indicates the direction of the main axis with the greatest variance and the eigenvalue indicates the magnitude of the variability of the secondary axis with the next variance. The Bartlett test was used to verify the measure of the correlation matrix and the identity matrix to indicate the existence of the relationship among variables evaluated and the Kaiser-Meyer-Olkin test (KMO) to measure the adequacy of data for the PCA [27].

For data referring to the number of insecticide applications in the agricultural year, canonical variates analysis (CVA) was performed using the procedure CANDISC on the SAS software Basic Edition, Cary, NC, USA (SAS Institute 2011) to verify possible linear associations of applications among locations in each region under study. Data on the use of chemical subgroups and number of applications were correlated using canonical correlation analysis (partial) in order to test the relationship among these variables using the PROC CANCORR procedure [28].

\section{Results}

The size of farms sampled in the survey ranged from 2 to 44 thousand hectares (Figure 2a), the cultivation area ranged from 0.5 to 1800 hectares (Figure $2 b$ ), and included farms without area of native vegetation and farms with up to 200 hectares of native vegetation (Figure 2c).

The variables presented in Table 1 and Figure 2 provide total components and the proportion of variance indicating the total variation of the principal component. For the total area component, two distinct axes were obtained, PC1 and PC2, accounting for $56.03 \%$ and $43.97 \%$ of the total variance observed (Figure 2a). These results indicate the prevalence of small farm size in the highlands (frequently lower than $100 \mathrm{ha}$ ), and a broader range of farm size variation in western Bahia with the prevalence of large farm size (i.e., $>200$ ha) (Figure 2a).

When the area cultivated with coffee was analyzed, linear correlations were also significant, with PC1 and PC2 representing $54.28 \%$ and $45.71 \%$ of variance, respectively. The profile of farms in their respective coffee cultivated areas closely follows the trend of overall farm size with greater coffee areas prevailing in the western region and small coffee areas prevailing in the highlands (Figure $2 b$ ), where more uniform and smaller farm (and coffee field) sizes prevail.

Areas covered with native vegetation and recognized as permanently maintained preservation areas were also surveyed for each farm in each region. The PC1 and PC2 obtained accounted for 62.61 and $37.39 \%$ of the observed variance, respectively (Figure 2c). Large areas of native vegetation are frequently associated with larger farm size, while smaller areas of native vegetation are associated with small farm size (Figure 2c).

The results indicated that the occupation of the farms with the coffee crop $\left(\chi^{2}=42.85 ; p<0.0001\right)$ is more expressive on smaller properties, on average, $62.4 \%$ of the total area is used with coffee in the highlands region, varying from $20 \%$ to $100 \%$, in the western, the average occupation with culture vary with an average of $19.3 \%$ (Figure $2 \mathrm{~d}$ ). With respect to the native vegetation area $\left(\chi^{2}=11.55\right.$; $p<0.0001$ ), most farms in the highlands have up to $20 \%$, and in the western $11 \%$ to $30 \%$ of the total area comprehend areas of vegetation reserve (Figure 2e). 
a) Farm size
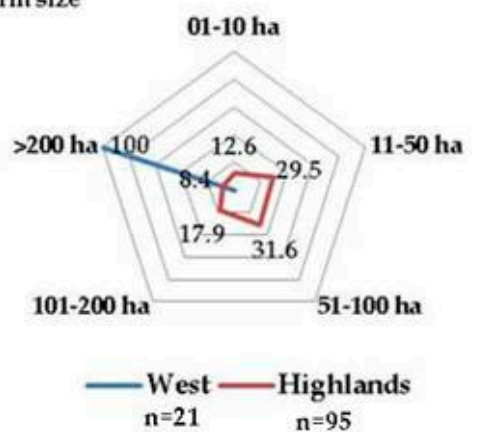

b) Area cultivated with coffee

01-10 ha

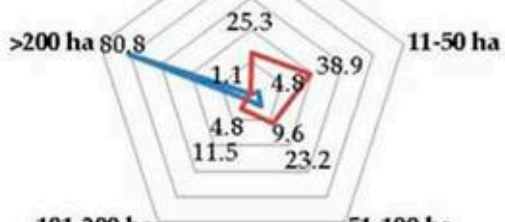

101-200 ha

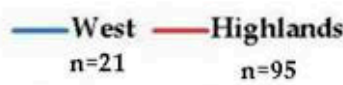

c) Area with native vegetation

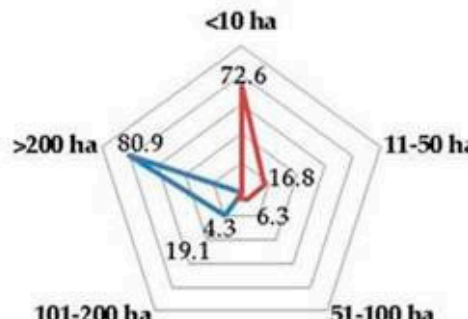

101-200 ha

51-100 ha

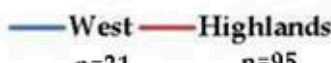

$\mathrm{n}=\mathbf{2 1} \quad \mathrm{n}=\mathbf{9 5}$

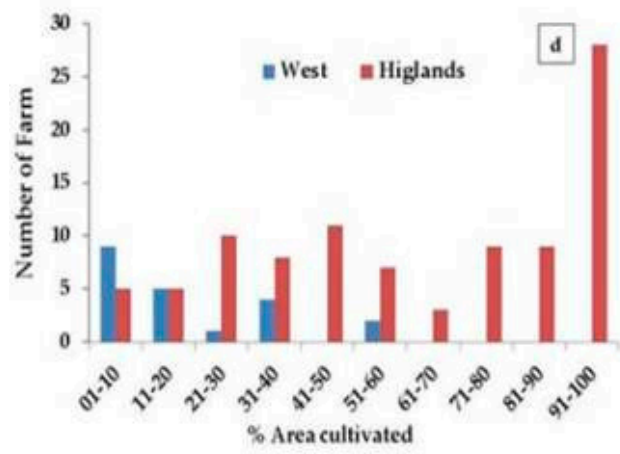

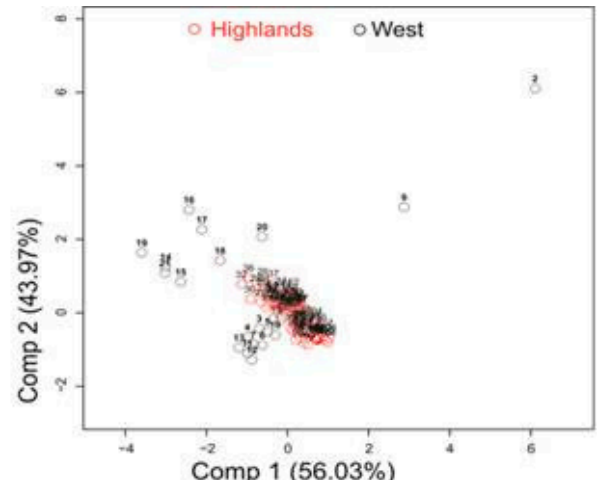
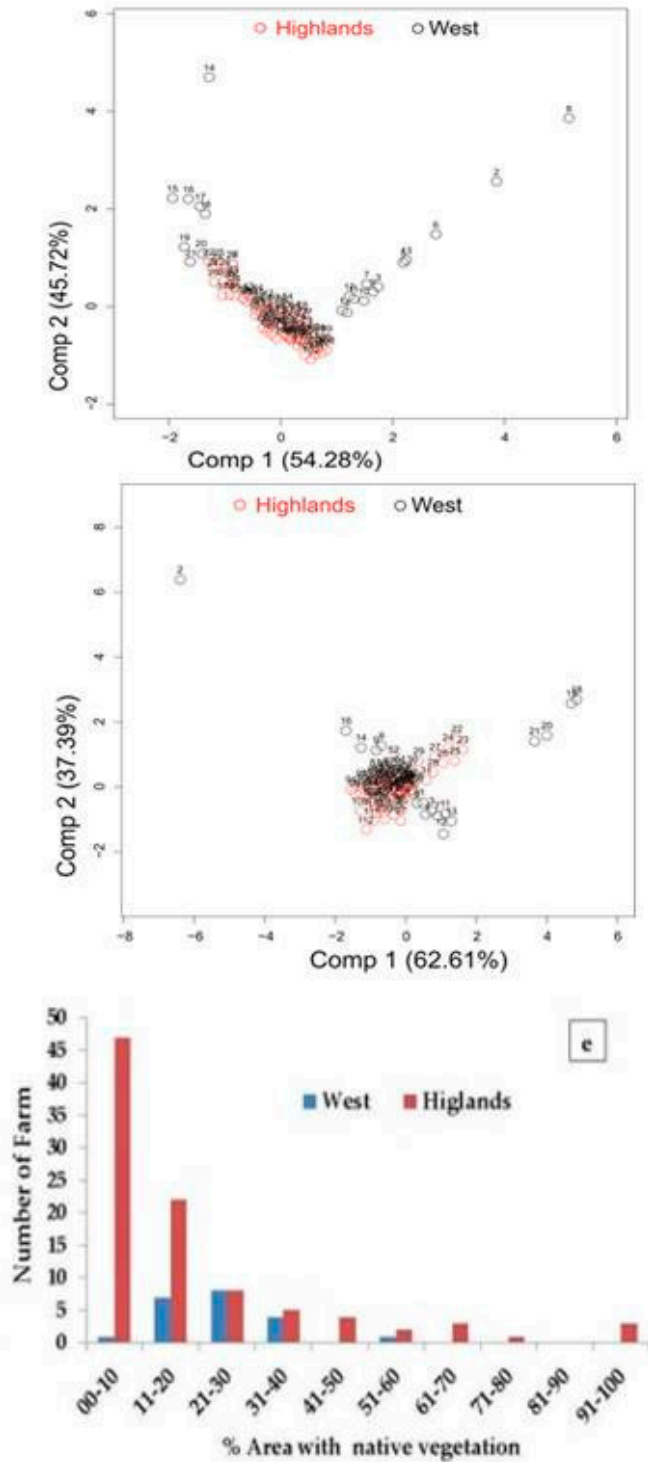

Figure 2. Percentage of coffee farmers' responses and graph of the matrix of 116 sampled farms, belonging to the western and south-central highlands regions of the state Bahia: Total area (a), area cultivated with Arabica coffee (b), area of native vegetation (c), percentage of area cultivated with coffee $(\mathbf{d})$, and native vegetation (e) in relation to total area. 
Table 1. Principal components, eigenvalues, proportion of explained variance, and proportion accumulated by components for total area, cultivated area and native vegetation area.

\begin{tabular}{cccc}
\hline Component & Eigenvalues & $\begin{array}{c}\text { Total Area } \\
\text { Proportion }\end{array}$ & Proportion Accumulated \\
\hline PC1 & 1.12 & 56.03 & 56.03 \\
PC2 & 0.87 & 43.96 & 100.00 \\
& & Cultivated Area & \\
PC1 & 1.08 & 54.28 & 54.28 \\
PC2 & 0.91 & 45.71 & 100.00 \\
& & Native Vegetation Area & \\
PC1 & 1.90 & 62.61 & 62.61 \\
PC2 & 0.89 & 37.39 & 100.00 \\
\hline
\end{tabular}

Data related to type of coffee cultivation $\left(\chi^{2}=6.00 ; p=0.014\right)$ and cultivars $\left(\chi^{2}=37.59 ; p<0.0001\right)$ indicated significant differences between regions. In the western region, $100 \%$ of coffee crops are irrigated, while non-irrigated cultivation prevails in the highland region (76.4\%) (Figure 3a). The 'Catuaí' cultivar is predominant in both regions, reaching $100.0 \%$ of the coffee cultivated area in the western region and $90.6 \%$ in the highland region (Figure $3 \mathrm{~b}$ ).
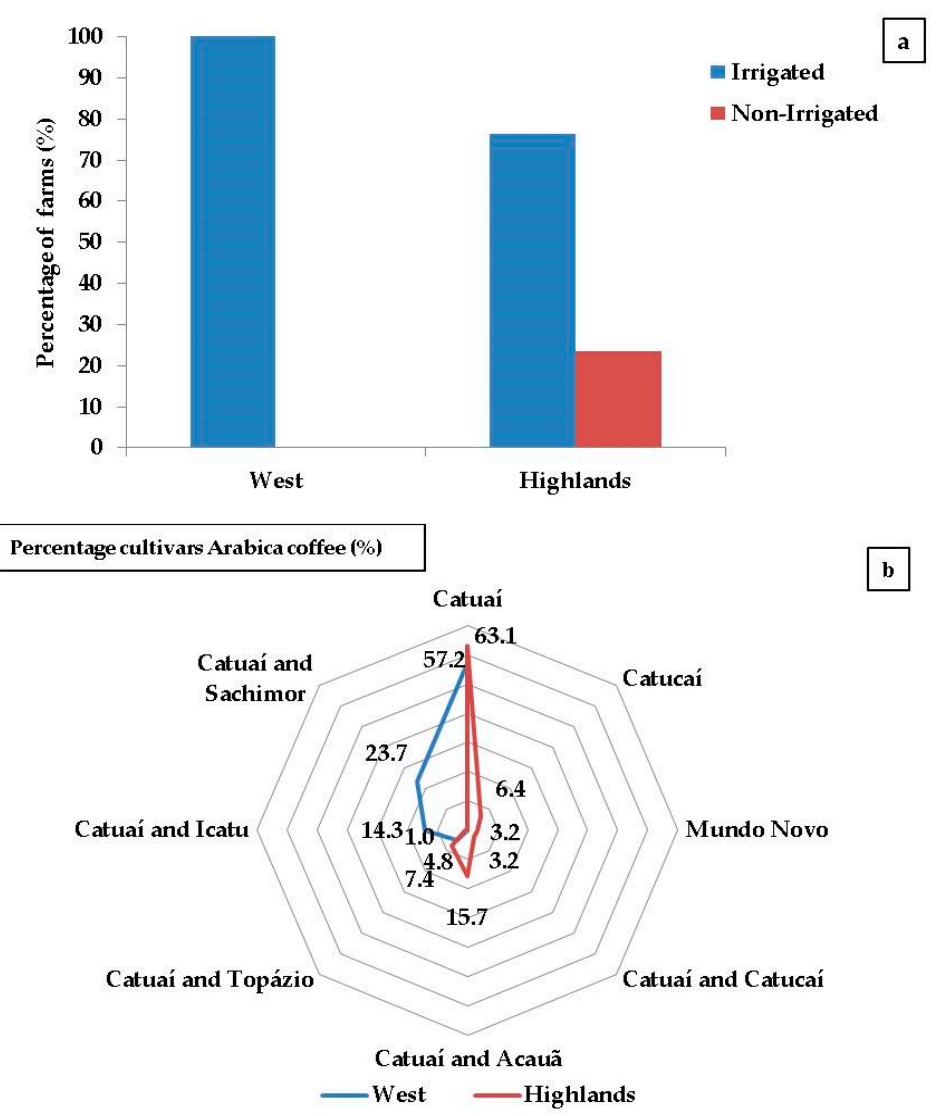

Figure 3. Irrigation prevalence (a) and prevailing cultivars of Arabica coffee (b) cultivated in the western and south-central highlands regions of the state Bahia.

Regarding the management of the coffee leaf miner, it was observed differences between regions $\left(\chi^{2}=12.11 ; p=0.0005\right)$, control tactics used $\left(\chi^{2}=7.86 ; p=0.048\right)$, use of insecticide rotation $\left(\chi^{2}=3.96\right.$; $p=0.046)$, and range of insecticide dose used $\left(\chi^{2}=33.81 ; p<0.0001\right)$, without difference in the level of control $\left(\chi^{2}=2.48 ; p=0.289\right)$. The infestation level of the coffee leaf miner is monitored by $76.2 \%$ (western region) and 34.7\% (highland region) of coffee growers (Figure 4a). However, most coffee 
growers in the western (95.2\%) and highland regions (93.7\%) do not consider the action (or control) threshold for decision-making, performing only non-quantitative (visual or qualitative) sampling for the adoption of chemical control (Figure $4 b$ ).
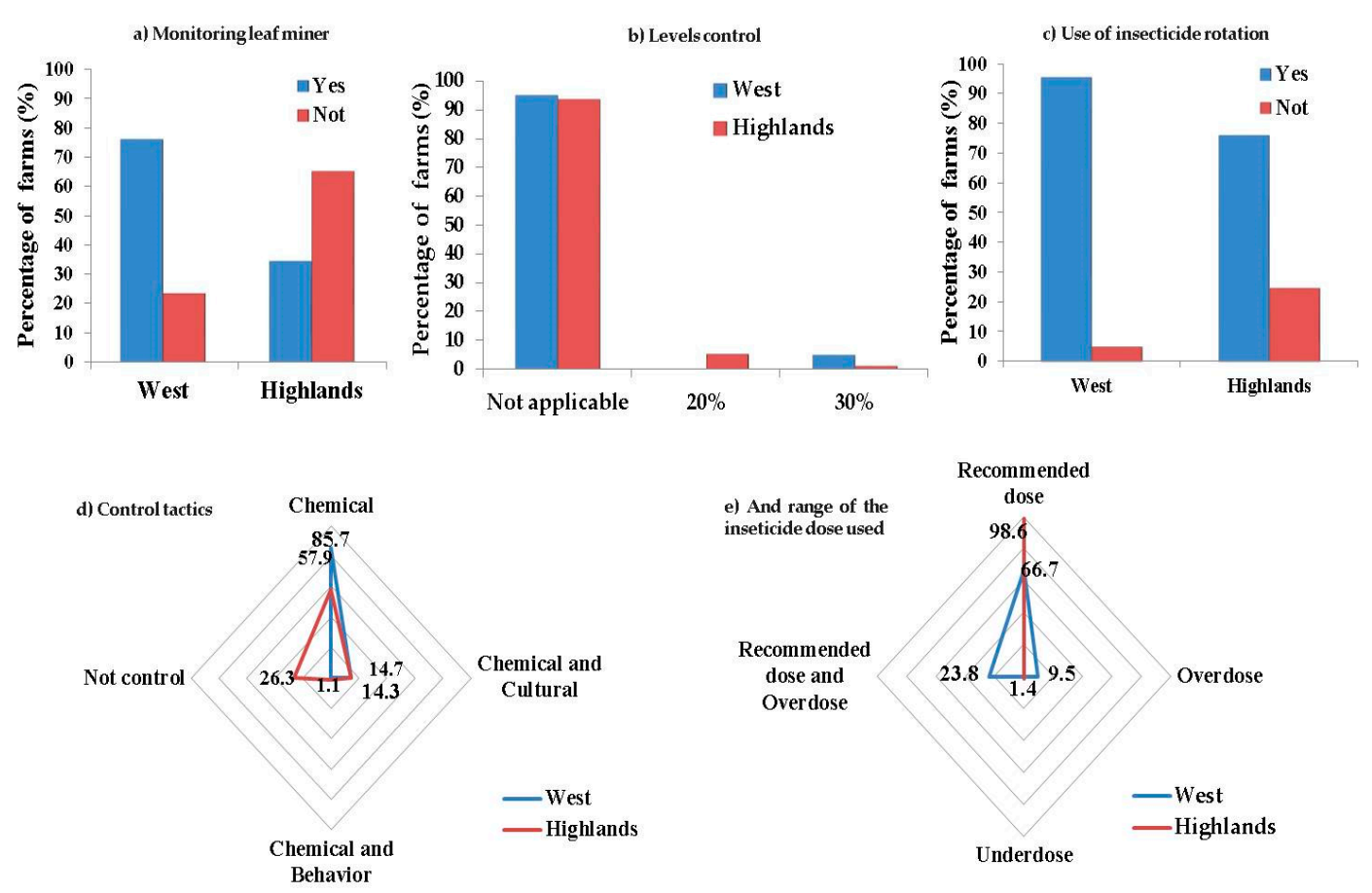

Figure 4. Percentage of responses of coffee farmers to the management of the Neotropical coffee leaf miner (Leucoptera coffeella): Monitoring leaf miner (a), levels control (b), use of insecticide rotation (c), control tactics (d), and range of the insecticide dose used (e) in Arabica coffee crops in the western and south-central highlands regions of the state Bahia.

The prevalent control method is chemical (i.e., by means of insecticide use), mainly in the western region where $100 \%$ of farms use insecticides, and only $14.3 \%$ associate chemical control with cultural management (e.g., weed management). In the highland region, $57.9 \%$ of coffee growers carry out only chemical control. On the other hand, $26.3 \%$ of coffee growers in the highland region do not adopt any control method, $14.7 \%$ associate chemical and cultural methods, and $1.1 \%$ associate chemical and behavioral methods through food bait (based on oleoresins and sugar, Noctovi ${ }^{\circledR}$ ) (Figure 4c,d).

The rotation of insecticides is carried out by the majority of coffee growers in the western $(95.2 \%)$ and highland regions (75.7\%). Among the coffee growers, $66.7 \%$ use the recommended label rate in western Bahia, and $98.6 \%$ use that in the highlands. About a third (33.3\%) of the coffee growers in western Bahia overdose the insecticide applications (Figure 4e).

Canonical correlation (partial) in the group of variables was formed by insecticide classes and their frequency of application (Table 2 and Figure 5), which was positive and significant. The main constituents of the canonical pair were based on values of correlations and canonical coefficients with the two canonical axes significant and the first axis explaining $99 \%$ of the total data variance for both western and highland regions (Table 2).

Absolute values of the highest coefficients were obtained for insecticides diamides, avermectin, nereistoxin analogs, neonicotinoids, and benzoylureas, which contributed to the pattern of divergence between number of applications among the different farms of the western region, in contrast with the diamide, neonicotinoid and benzoylurea more frequent use in the highland region (Figure 5). The first canonical axis of the greatest weight in the analysis indicates frequent use in the western region of all insecticide classes, except organophosphate and pyrethroids (Table 2). The use of diamides prevailed in the highlands and insecticides with more uniform use of insecticides from different classes, and lack 
of use of nereistoxin analogs (Table 2 and Figure 5). It was observed that in the highland region, the frequency of insecticide applications is lower in comparison to the western region. The range of annual insecticide applications is one to 12 applications in the highlands, and 6 to 20 applications in the western region.

Table 2. Canonical axes and coefficients (grouped in the canonical structure) of the frequency of application of insecticides of the different classes used in the control of Leucoptera coffeella in the west and highlands regions of Bahia.

\begin{tabular}{ccccc}
\hline & \multicolumn{4}{c}{ Canonical Axes } \\
\cline { 2 - 5 } Variable & \multicolumn{3}{c}{ West } & \multicolumn{2}{c}{ Highlands } \\
\cline { 2 - 5 } & $\mathbf{1}$ & $\mathbf{2}$ & $\mathbf{1}$ & $\mathbf{2}$ \\
\cline { 2 - 5 } & 0.5070 & -0.1915 & 0.7548 & -0.2161 \\
Diamide & 0.4467 & -0.2930 & 0.5815 & -0.1152 \\
Neonicotinoids & 0.1424 & -0.2875 & 0.6578 & 0.1237 \\
Pyrethroids & 0.5694 & 0.0037 & 0.3793 & -0.0096 \\
Avermectin & 0.5996 & 0.3062 & 0.4246 & 0.4954 \\
Benzoylurea & -0.1109 & 0.6159 & 0.4268 & -0.0131 \\
Organophosphate & 0.6256 & 0.7459 & - & - \\
Nereistoxin analogs & 140.96 & 12.43 & 338.29 & 8.70 \\
F & $14 ; 24$ & $6 ; 13$ & $12 ; 174$ & $5 ; 88$ \\
Degrees of Freedom (num.; den) & $<0.0001$ & $<0.0001$ & $<0.0001$ & $<0.0001$ \\
$\boldsymbol{p}$ & 0.99 & 0.85 & 0.99 & 0.33 \\
Canonical squared correlation & & &
\end{tabular}
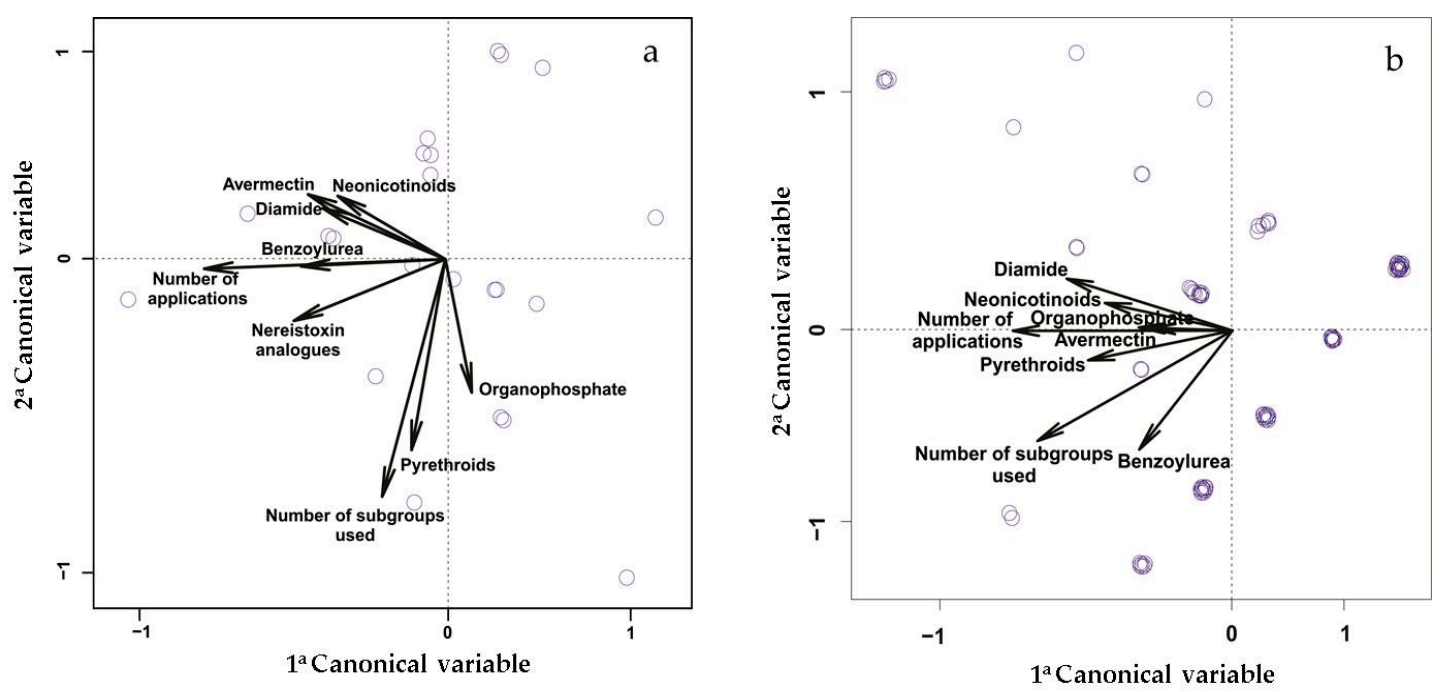

Figure 5. Ordination diagram showing the discrimination between the frequency of application of insecticides for the chemical control of Leucoptera coffeella populations in the western (a) and highlands (b) regions of Bahia. The symbols are centroid of the localities and represent the average of the classes of canonical variables. The vectors indicate groups of farms without significant difference between them (Wilks' Lambda and approximate F, $p<0.001$ ).

The application interval for a product is, on average, 20 days. Products without registration with the Ministry of Agriculture and Livestock [29] for coffee crop, such as Ampligo ${ }^{\circledR}$ (lamdacyhalothrin + chlorantraniliprole), Interprid ${ }^{\circledR}$ (methoxyfenozide), Dimilin ${ }^{\circledR}$ (diflubenzuron), Match ${ }^{\circledR}$ (lufenuron), Oregon ${ }^{\circledR}$ (novaluron), Talisman ${ }^{\circledR}$ (bifenthrin + carbosulfan) are used by some coffee growers in both regions. 


\section{Discussion}

Descriptive analyses, PCA, and the correlations indicated differences between Arabica coffee producing regions of Bahia, as to the size of the farms, occupation of the land with the coffee crops, and native vegetation, adoption of irrigation and, in some aspects, of the management of the leaf miner. In western Bahia, farms are characterized by larger extensions, with areas of up to 44 thousand hectares and areas of coffee reaching 1800 hectares, exhibiting permanent preservation areas in compliance with Brazilian Forest Code (Law 4771/65), a minimum of $20 \%$ of the total area. In highlands, most of the farms have smaller extensions, from 2 to 350 hectares (Figure 2a), in some cases, totally occupied with the coffee crop, with a more heterogeneous permanent reserve occupancy rate among the farms.

Coffee production of western Bahia stands out for having $100 \%$ of the coffee area completely irrigated (center-pivot and drip irrigation), contrasting with the prevalent non-irrigated coffee of the highland region. The predominant cultivar in these regions is the 'Catuai', which is characterized by being of small size, short internodes, abundant secondary branching, red (cultivar IAC 144), or yellow (cultivar IAC 62) fruits of medium to late maturation, high yield and adaptation to extreme temperatures [30]. However, besides to areas cultivated with Catuaí, other cultivars such as 'Acauã', 'Mundo Novo' and 'Catucaí' are also used only in the highland region, while the 'Sarchimor' cultivar is present only in the western region.

These differences reflect in several aspects of the coffee production chain, with mechanized systems and outsourced manpower in the western region, enabling the management of crop in macro scale. Coffee crops in this region is characterized by present productivity above the national Brazilian average and using agricultural inputs, irrigation, appropriate genotypes, and mechanization, among other practices. The climate is favorable to the quality of the coffee, because at the time of harvest, conditions of low relative humidity of the air occur, with the rains concentrated in the summer [31]. In highlands, the use of inputs is less intense and family manpower predominates. The specificities of some microregions in the highlands, such as the Chapada Diamantina, about the climate and the realization of selective and manual harvesting of the fruits, have guaranteed the production of special coffees of excellent quality, with high value aggregated [32].

In the last two years, only one farm in the western region did not show infestation by the coffee leaf miner due to the monitoring used and the application of insecticides in a preventive way in order not to compromise coffee production. However, the other farms have a history of high infestation by the coffee leaf miner resulting in a higher frequency of insecticide applications. In the highland region, some crops fields located in the municipalities of Piatã, Ibicoara, Barra da Estiva, and Vitória da Conquista have low infestation levels, and without a history of insecticide application for over a decade. On the other hand, crops located on municipality Mucugê presented high infestations by the coffee leaf miner in the last five years. This fact caused serious problems for coffee growers, resulting in an increasing number of applications of different insecticide classes.

When asked whether or not to carry out monitoring of the coffee leaf miner, most respondents carried out monitoring, which is the basis for IPM. However, throughout the interview, it was observed that the concept of monitoring is not suitably adopted in practice. This is because, in most cases, the monitoring performed is a visual, non-quantitative, and non-systematic analysis based only on the presence or absence of live larvae detected in quick and casual visual observation. Interestingly, there is no shortage of studies on sampling of the coffee leaf miner, both with conventional [33] and sequential plans [34]. Another problem detected in the survey is that the percentages of predation and natural parasitism are also not quantified by coffee growers [35]. Thus, decision-making about whether or not to use a control method, another IPM support pillar, is not based on the analysis of numerical variations of pest populations and their main natural enemies. The consequence of such neglect of the preventive use of insecticides for leaf miner resulting in insecticide overuse and unnecessary increase in production costs [36].

Quantitative population assessments based on activity levels and economic injury thresholds form the basis of IPM to minimize unnecessary interventions for pest population suppression, especially by the 
chemical method. When correctly performed and based on a validated sampling plan, monitoring favors decision-making with reduced application of insecticides and reduced production costs. Despite the economic and environmental advantages resulting from the use of the limit established for decision making in agriculture pest management [37,38], their effective use remains as one of the main obstacles to the use of IPM programs in various agricultural crops in Brazil and worldwide $[5,37,39,40]$. On the other hand, IPM plays a fundamental role in adapting production systems to the trends of modern agriculture for the economic benefit of growers and the reduction of environmental impacts [5,41-43].

Although there are edaphoclimatic differences between regions, the coffee leaf miner occurs throughout the year in Bahia, finding optimal conditions for its development in the western region (low relative humidity and high temperatures) and favorable conditions in the south-central highland region (lower temperatures and high relative humidity at certain times of the year). However, in the highlands at altitudes around $1000 \mathrm{~m}$ and average annual temperature of around $20^{\circ} \mathrm{C}$, the coffee leaf miner population remains at the equilibrium level for most of the year, with the presence of at least six species of parasitoids that act in the pest regulation [44]. The same species of parasitoids have also been observed in the western region in coffee crops located in Luis Eduardo Magalhães, which has an average annual temperature of approximately $24.3^{\circ} \mathrm{C}$, but with lower parasitism rates and with variations in the structure of their communities [44].

Most coffee growers adopt only chemical control for coffee leaf miner population suppression, an aspect that, associated with lack of suitable monitoring for control decision-making, impairs the proper use of IPM in coffee farms of the region. With rare exceptions, there are coffee growers in both regions who adopt chemical and cultural controls. On the other, $26.3 \%$ of highlands coffee growers do not use any control tactics for the leaf miner, which reveals that the insect meets a "non-pest" situation, probably due to the regulation of its population by factors, such as parasitoid wasps and predators whose survival and permanence in coffee plantations are favored by the absence of insecticides, higher altitude of the region (1000 to $2000 \mathrm{~m}$ ), and lower average temperatures in relation to the western region. In some cases, coffee growers have not used insecticides for more than 15 years, with the reestablishment of beneficial fauna.

In the case of coffee production, this agro-ecosystem has the capacity of harboring several natural enemies [45]. The harmonization of these practices tends to reduce impacts on the communities of predators and parasitoids, reducing the incidence of the coffee leaf miner. According to Faria and Angelini [46], cultural control aids chemical control by reducing the incidence of the coffee leaf miner in coffee crops. Another important data obtained in the survey was the use of behavioral control using the Noctovi ${ }^{\circledR}$ food-based attractant in a farm located in the municipality of Barra do Choça (highland). Such use allows the recording of the pest population dynamics and can be used simultaneously with insecticides.

Vegetation diversification reduces the pest incidence favoring and providing alternative foods to natural enemies [47]. Natural enemies, such as parasitoids, are efficient when associated with integrated management of the coffee leaf miner [44,48,49], and the use of more selective insecticides favors their prevalence in coffee crops [22,50].

Organophosphate, carbamate, and pyrethroid insecticides were the most used in the control of the coffee leaf miner, but other insecticide classes were more recently introduced and are broadly used against the coffee leaf miner, including neonicotinoids [51], diamides [52], avermectins [53], all of which act on the nervous system, and benzoylureas, which are insect growth disruptors interfering with chitin synthesis, a major component of the insect exoskeleton [54]. Interestingly, rather than rotating the insecticide molecules for controlling the coffee leaf miner, a pivotal recommendation to minimize selection for insecticide resistance in pest species, the growers tend to rotate trade names or formulations, frequently maintaining the use of the same insecticide, but using different commercial products. Thus, no wonder insecticide resistance is a problem in the region against this pest species [25].

The frequent use of insecticides causes selection pressure on pest individuals, favoring the emergence of individuals resistant to products used in their control [24], leading coffee growers to 
use an overdose of product, greater number of applications, and consequently, replacement of an ineffective insecticide by a new insecticide [55-57]. Fragoso et al. [23] reported the applications of 22 insecticides in a year, 10 of which were organophosphates. Furthermore, many coffee growers make frequent use of insecticides, including relatively more persistent and less selective compounds. Such patterns of insecticide use enhance insecticide resistance risk and environmental problems [22].

A concerning piece of data regarding the use of insecticides in the western region is the residual period indicated by manufacturers, which is not respected by coffee growers. The application interval for a product is, on average, 20 days. In addition to data on the coffee leaf miner management, products without registration with the Ministry of Agriculture and Livestock [29] should not be used according to the regulation of Law No. 7.802 of July 11, 1989, Art.73. Nonetheless, the use of unregistered products is one of the major problems faced when thinking about adapting production to the trends of modern agriculture, as observed for custard apple (Annona squamosa L.) crops [58].

There is an increase in the frequency of annual applications of the neonicotinoids thiamethoxam and imidacloprid (two to four) and uniform use of the same compounds in several farms of the region, which increases the risk of selecting for insecticide resistance. Such a trend takes place regardless of the size of cultivated area, climate, temperature, and rainfall.

It is noteworthy that the greater the number of applications and use of insecticides with the same site of action, the greater the likelihood of insecticide resistance. Most coffee growers use an application schedule, not considering parameters population trend coffee leaf miner and natural enemy population densities [32]. Nonetheless, measures for the successful reduction of the pest population must be carried out considering ecological, environmental, and economic and food security aspects for sustainable and high-quality coffee production. Therefore, there is an urgent need for integrative action between research and extension agencies, agricultural companies and coffee growers to expand the use of IPM principles in line with global agriculture megatrends, which are the bases for the sustainability of agriculture production chains [59].

Author Contributions: The following statements should be used. Conceptualization, S.A.L., M.A.C. and R.N.C.G.; methodology, S.A.L. and M.A.C.; software, S.A.L. and M.P.d.S.; formal analysis, S.A.L., M.P.d.S. and M.A.C.; investigation, S.A.L. and M.A.C.; resources, S.A.L. and M.A.C.; writing-original draft preparation, S.A.L. and M.A.C.; writing-review and editing, S.A.L., M.P.d.S., D.R.d.C., A.A.M., S.N.M., O.L.L., R.N.C.G. and M.A.C. All authors have read and agreed to the published version of the manuscript.

Funding: This research was funded by CAPES Foundation (Brazilian Ministry of Education) Finance Code 001.

Acknowledgments: We are grateful to the Foundation for Research Support of the State of Bahia (FAPESB). We express our gratitude to the coffee farmers of western Bahia and the Bahia south-central highlands, the ABACAFÉ and its consultants, and the companies Agrícola Marçal, DNA Agrícola, Módulo Rural and PlanteBem for the support provided.

Conflicts of Interest: The authors declare no conflict of interest.

\section{References}

1. Righi, C.A.; Campoe, O.C.; Bernardes, M.S.; Lunz, A.M.P.; Piedade, S.D.S.; Pereira, C.R. Influence of rubber trees on leaf-miner damage to coffee plants in an agroforestry system. Agrofor. Syst. 2013, 87, 1351-1362. [CrossRef]

2. CONAB; Companhia Nacional de Abastecimento. Acompanhamento da Safra Brasileira Café. Safra 2020, n.1-Primeiro Levantamento, ISSN 2318-7913, Brasília, Brazil. Available online: http://www.conab.gov.br (accessed on 30 May 2020).

3. Castellani, M.A.; Melo, T.L.; Menezes, M.A.P. Desafios para o manejo do bicho-mineiro. Aiba Rural 2016, 5, 40-41.

4. Świtek, S.; Sawińska, Z. Farmer rationality and the adoption of greening practices in Poland. Sci. Agric. 2017, 74, 275-284. [CrossRef]

5. Sawińska, Z.; Świtek, S.; Głowicka-Wołoszyn, R.; Kowalczewski, P.L.; Głowicka-Wołoszyn, R. Agricultural practice in Poland before and after mandatory IPM implementation by the European Union. Sustainabillity 2020, 12, 1107. [CrossRef] 
6. Ha, T.M. A rewiev on the development of integrated pest management and its integration in modern agriculture. Asianj. Agricul. Food Sci. 2014, 2, 336-340.

7. Dara, S.K. The new integrated pest management paradigm for the modern age. J. Integr. Pest. Manag. 2019, 10, 1-9. [CrossRef]

8. Ehler, L. Integrated pest management (IPM): Definition, historical development and implementation, and the other IPM. Pest. Manag. Sci. 2006, 62, 787-789. [CrossRef]

9. Zalucki, M.P.; Adamson, D.; Furlong, M.J. The future of IPM: Whither or wither? Aust. J. Ėntomol. 2009, 48, 85-96. [CrossRef]

10. Crocomo, W.B. Manejo Integrado de Pragas, 1st ed.; Editora Universidade Estadual Paulista: Botucatu, Brazil, 1990; p. 358.

11. Guedes, R.N.C.; Tuelher, E.S.; De Oliveira, E.E.; Magalhães, L.C. Ocorrência de bicho-mineiro do cafeeiro (Leucoptera coffeella) influenciada pelo período estacional e pela altitude. Acta Sci. Agron. 2003, 25, 119-124. [CrossRef]

12. Pereira, E.J.G.; Picanço, M.; Bacci, L.; Crespo, A.; Guedes, R.N.C. Seasonal mortality factors of the coffee leaf miner, Leucoptera coffeella. Bull. Èntomol. Res. 2007, 97, 421-432. [CrossRef]

13. Pereira, E.J.G.; Picanço, M.C.; Bacci, L.; Della Lucia, T.M.C.; Silva, É.M.; Fernandes, F.L. Natural mortality factors of Leucoptera coffeella (Lepidoptera: Lyonetiidae) on Coffea arabica. Biocontrol Sci. Technol. 2007, 17, 441-455. [CrossRef]

14. Magalhães, S.; Fernandes, F.L.; Demuner, A.J.; Picanço, M.C.; Guedes, R.N.C. Leaf alkaloids, phenolics, and coffee resistance to the leaf miner Leucoptera coffeella (Lepidoptera: Lyonetiidae). J. Econ. Ėntomol. 2010, 103, 1438-1443. [CrossRef]

15. Pantoja-Gomez, L.M.; Correa, A.S.; De Oliveira, L.O.; Guedes, R.N.C. Common Origin of Brazilian and Colombian Populations of the Neotropical Coffee Leaf Miner, Leucoptera coffeella (Lepidoptera: Lyonetiidae). J. Econ. Èntomol. 2019, 112, 924-931. [CrossRef]

16. Parra, J.R.P.; Reis, P.R. Manejo integrado para as principais pragas da cafeicultura, no Brasil. Visão Agrícola-Fitossanidade 2013, 12, 47-50.

17. Enríquez, E.; Bejarano, S.; Vila, V. Morfología, ciclo biológico y comportamiento de Leucoptera coffeella. Guer.-Men. Rev. Per. Entomol. 1975, 18, 79-81.

18. De Custódio, A.A.P.; Moraes, J.C.; de Custódio, A.A.P.; Lima, L.A.; de Faria, M.A.; Gomes, N.M. Incidência do bicho-mineiro do cafeeiro em lavoura irrigada sob pivô central. Coffee Sci. 2009, 4, 16-26.

19. Fragoso, D.; Guedes, R.N.C.; Picanço, M.; Zambolim, L. Insecticide use and organophosphate resistance in the coffee leaf miner Leucoptera coffeella (Lepidoptera: Lyonetiidae). Bull. Èntomol. Res. 2002, 92, 203-212. [CrossRef]

20. Ramiro, D.A.; Guerreiro-Filho, O.; Queiroz-Voltan, R.B.; Matthiesen, S.C. Caracterização anatômica de folhas de cafeeiros resistentes e suscetíveis ao bicho-mineiro. Bragantia 2004, 63, 363-372. [CrossRef]

21. Gao, C.-F.; Su, J.; Yao, R.; Zhang, Z.; Wu, M. Susceptibility Baseline and Chlorantraniliprole Resistance Monitoring in Chilo suppressalis (Lepidoptera: Pyralidae). J. Econ. Èntomol. 2013, 106, 2190-2194. [CrossRef]

22. Costa, D. Resistance to neurotoxic insecticides in populations of the coffee leafminer Leucoptera coffeella. In Insecticides Resistance; Intech Open: London, UK, 2016; pp. 3-17.

23. Fragoso, D.B.; Guedes, R.N.C.; Ladeira, J.A. Seleção na evolução de resistência a organofosfatos em Leucoptera coffeella (Guérin-Mèneville) (Lepidoptera: Lyonetiidae). Neotrop. Entomol. 2003, 32, 329-334. [CrossRef]

24. Ribeiro, B.M.; de Magalhães, L.C.; Guedes, R.N.C. Níveis de resistência a inseticidas organo-fosforados em populações de Leucoptera coffeella (Guèr-Ménev) (Lepidoptera: Lyonetiidae) de Minas Gerais. Biosc. J. 2003, $19,73-77$.

25. Leite, S.A.; dos Santos, M.P.; Resende-Silva, G.A.; da Costa, D.R.; Moreira, A.A.; Lemos, O.L.; Guedes, R.N.C.; Castellani, M.A. Area-Wide Survey of Chlorantraniliprole Resistance and Control Failure Likelihood of the Neotropical Coffee Leaf Miner, Leucoptera coffeella (Lepidoptera: Lyonetiidae). J. Econ. Èntomol. 2020, 113, 1399-1410. [CrossRef]

26. Lé, S.; Josse, J.; Husson, F. FactoMineR: An R Package for Multivariate Analysis. J. Stat. Softw. 2008, 25, 1-18. [CrossRef]

27. Cruz-Jesus, F.; Oliveira, T.; Bação, F.; Irani, Z. Assessing the pattern between economic and digital development of countries. Inf. Syst. Front. 2016, 19, 835-854. [CrossRef]

28. SAS Institute. SAS/STAT9.3 User's Guide; SAS Institute: Cary, NC, USA, 2011. 
29. Ministério da Agricultura Pecuária e Abastecimento (MAPA). AGROFIT: Sistema de Agrotóxicos Fitossanitários. MAPA/CGAF/DFIA/DAS, Brasília, DF, Brasil 2020. Available online: http://agrofit.agricultura.gov.br/agrofit_ cons/principal_agrofit_cons (accessed on 27 January 2020).

30. De Freitas, Z.M.T.S.; De Oliveira, F.J.; De Carvalho, S.P.; Dos Santos, V.F.; Santos, J.P.D.O. Avaliação de caracteres quantitativos relacionados com o crescimento vegetativo entre cultivares de café arábica de porte baixo. Bragantia 2007, 66, 267-275. [CrossRef]

31. Fernandes, A.L.T.; Partelli, F.L.; Bonomo, R.; Golynski, A. A moderna cafeicultura dos cerrados brasileiros. Pesqui. Agropecuária Trop. 2012, 42, 231-240. [CrossRef]

32. Bandeira, F.P. Café da Chapada Diamantina ganha o mundo. Secretária de Agricultura do Estado da Bahia 2017, 6-25.

33. Picanço, M.C.; Martins, J.C.; Oliveira, I.R.; Martinez, H.E.P.; Milagres, C.C. Plano de Amostragem Convencional do Bicho Mineiro Através de Contagem de Minas com Lagartas e Cafeeiro em Formação. Anais do Simpósio de Pesquisa dos Cafés do Brasil, Londrina, Paraná. Embrapa Café, Brasília, Distrito Federal, Brazil. 2005, 4. Available online: http://www.sbicafe.ufv.br/handle/123456789/1873 (accessed on 21 May 2020).

34. Vieira Neto, J.; Aquino, L.H.; Bearzoti, E.; Souza, J.C. Otimização da amostragem sequencial para o monitoramento do bicho-mineiro do cafeeiro Perileucoptera coffeella (Lepidoptera: Lyonetiidae) em Lavras, Minas Gerais. Cien. Agrotec. 1999, 23, 707-718.

35. Picanço, M.C.; de Oliveira, I.R.; Fernandes, F.L.; Martinez, H.E.P.; Bacci, L.; da Silva, E.M. Ecology of vespidae (Hymenoptera) predators in Coffea arabica plantations. Sociobiology 2012, 59, 1269-1280.

36. Souza, J.C.; Reis, P.R. Pragas do Cafeeiro-Reconhecimento e Controle; CTP: Viçosa, Brazil, 2000; p. 154.

37. Picanço, M.C.; De Paula, S.V.; Junior, A.R.M.; De Oliveira, I.R.; Semeão, A.A.; Rosado, J.F. Impactos financeiros da adoção de manejo integrado de pragas na cultura do tomateiro. Acta Sci. Agron. 2004, 26, 245-252. [CrossRef]

38. Alam, M.Z.; Crump, A.R.; Haque, M.; Islam, S.; Hossain, E.; Hasan, S.B.; Hasan, S.B.; Hossain, S. Effects of Integrated Pest Management on Pest Damage and Yield Components in a Rice Agro-Ecosystem in the Barisal Region of Bangladesh. Front. Environ. Sci. 2016, 4, 22. [CrossRef]

39. Bortolotto, O.C.; Pomari-Fernandes, A.; Bueno, R.C.O.D.F.; Bueno, A.D.F.; Da Cruz, Y.K.; Sanzovo, A.; Ferreira, R.B. The use of soybean integrated pest management in Brazil: A review. Agron. Sci. Biotechnol. 2015, 1, 25-32. [CrossRef]

40. Dhawan, A.K. Integrated pest management in cotton. In Integrated Pest Management in the Tropics; Dharam, P., Ed.; New India Publishing Agency: New Delhi, India, 2016; pp. 499-575.

41. Bueno, A.D.F.; Batistela, M.J.; Bueno, R.C.; França-Neto, J.D.B.; Nishikawa, M.A.N.; Filho, A.L. Effects of integrated pest management, biological control and prophylactic use of insecticides on the management and sustainability of soybean. Crop. Prot. 2011, 30, 937-945. [CrossRef]

42. Staback, D.; Blanck, P.L.; Mariussi, V.; Galante, V.A. Uso do MIP como estratégia de redução de custos na produção de soja no estado do Paraná. Rev. Am. Empr. Inov. 2020, 2, 187-200.

43. Varela, D.; Monteiro, F.; Vidigal, P.; Silva, L.; Romeiras, M.M. Mechanisms implemented for the sustainable development of agriculture: An overview of Cabo Verde performance. Sustainability 2020, 12, 5855. [CrossRef]

44. Melo, T.L.; Castellani, M.A.; Nascimento, M.D.L.D.; Junior, A.D.O.M.; Ferreira, G.F.P.; Lemos, O.L. Comunidades de parasitóides de Leucoptera coffeella (Guérin-Mèneville \& Perrottet, 1842) (Lepidoptera: Lyonetiidae) em cafeeiros nas regiões Oeste e Sudoeste da Bahia. Ciência Agrotecnol. 2007, 31, 966-972. [CrossRef]

45. Reis, P.R.; Souza, J.C.; Venzon, M. Manejo das principais pragas do cafeeiro. Informe Agropecuário 2002, 23, 83-99.

46. Faria, S.C.Q.D.S.; Angelini, M.R. Influência do manejo de plantas daninhas na incidência do bicho-minerio Leucoptera coffeella (Guérin-Méneville, 1842) (Lepidoptera: Lyonetiidae) na Região do cerrado mineiro. Enciclopédia Biosf. 2015, 11, 2022-2027. [CrossRef]

47. Amaral, D.S.; Venzon, M.; Pallini, A.; De Lima, P.C.; De Souza, O.F.F. A diversificação da vegetação reduz o ataque do bicho-mineiro-do-cafeeiro Leucoptera coffeella (Guérin-mèneville) (Lepidoptera: Lyonetiidae)? Neotrop. Èntomol. 2010, 39, 543-548. [CrossRef]

48. Fragoso, D.B.; Jusselino-Filho, P.; Guedes, R.N.C.; Proque, R. Seletividade de inseticidas a vespas predadoras de Leucoptera coffeella (Guér.-Mènev.) (Lepidoptera: Lyonetiidae). Neotrop. Ėntomol. 2001, 30, 139-143. [CrossRef] 
49. Souza, T.P.; Castellani, M.A.; de Lemos, R.N.S.; Pérez-Maluf, R.; Moreira, A.A.; Silva, B.S.; Ribeiro, E.B. Ocorrência sazonal, predação e parasitismo de Leucoptera coffeella (Guérin-Méneville, 1842) (Lepidoptera: Lyonetiidae) em cafeeiros associados a grevíleas. Coffee Sci. 2014, 9, 34-50.

50. Melo, T.L.; Raetano, C.G.; Nery, M.S.; Cardoso, A.D.; Moreira, A.A.; Leite, S.A.; De Jesus, T.F.; Silva, W.G.O.; Castellani, M.A. Management of coffee leaf miner: Spray volume, efficacy of Cartap Hydrochloride and impact on parasitism. Coffee Sci. 2019, 14, 250-260. [CrossRef]

51. Nauen, R.; Ebbinghaus-Kintscher, U.; Elbert, A.; Jeschke, P.; Tietjen, K. Acetylcholine Receptors as Sites for Developing Neonicotinoid Insecticides. In Biochemical Sites of Insecticide Action and Resistance; Springer Science and Business Media LLC: Berlin, Germany, 2001; pp. 77-105.

52. Lahm, G.P.; Cordova, D.; Barry, J.D. New and selective ryanodine receptor activators for insect control. Bioorganic Med. Chem. 2009, 17, 4127-4133. [CrossRef] [PubMed]

53. Ministério da Agricultura Pecuária e Abastecimento (MAPA). Sistema de Agrotóxicos Fitossanitários. MAPA/CGAF/DFIA/DAS, Certificado de Registro de Agrotóxico Avermectina com Finalidade http://agrofit. agricultura.gov.br/agrofit_cons/principal_agrofit_cons Fitossanitária para o Controle de Leucoptera coffeella, Brasília, DF, Brasil. 2008. Available online: http://agrofit.agricultura.gov.br/agrofit_cons/!ap_produto_form_ detalhe_cons?p_id_produto_formulado_tecnico=5422\&p_tipo_janela=NEW (accessed on 27 March 2020).

54. Ministério da Agricultura Pecuária e Abastecimento (MAPA). Sistema de Agrotóxicos Fitossanitários. MAPA/CGAF/DFIA/DAS, Certificado de Registro de agrotóxico Benzoilureia com Finalidade Fitossanitária para o Controle de Leucoptera coffeella, Brasília, DF, Brasil. 2009. Available online: grofit.agricultura.gov.br/agrofit_cons/ !ap_produto_form_detalhe_cons?p_id_produto_formulado_tecnico=8918\&p_tipo_janela=NEW (accessed on 27 March 2020).

55. Georghiou, G.P. Management of Resistance in Arthropods; Springer Science and Business Media LLC: Berlin, Germany, 1983; pp. 769-792.

56. Guedes, R.N.C.; Oliveira, E.E. Resistência a inseticidas-pragas do cafeeiro: Situação e perspectivas. In Oestado da Arte de Tecnologias na Produção de Café, 1st ed.; Zambolim, L., Ed.; UFV: Viçosa, Brazil, 2002; pp. 471-497.

57. Fernandes, F.L.; Bacci, L.; Fernandes, M.S. Impact and selectivity of insecticides to predators and parasitoids. EntomoBrasilis 2010, 3, 1-10. [CrossRef]

58. Oliveira, A.D.S.; Castellani, M.A.; Nascimento, A.S.D.; Moreira, A.A. Perfil do sistema de produção de pinha nos polos de fruticultura da Bahia, com ênfase nos aspectos fitossanitários da cultura. Extensão Rural 2016, 23, 95. [CrossRef]

59. Visão 2030: O Futuro da Agricultura Brasileira; Embrapa: Brasília, Brazil, 2018; p. 212. 